\section{Biological Vectors and Reservoirs of Strontium-90}

THE dispersion of radioactive contamination in the environment by mobile organisms has been reported by several authors. Davis ${ }^{1}$ noted significant amounts of radioactivity in caddis flies and midges (Orthocladiinae) attracted to lights from the nearby Columbia River. As the result of aquaria investigations on the uptake of radionuclides by aquatic insects, Peredelskii and Bogatyrev concluded that a bioecological purification of contaminated reservoirs would occur as the consequence of emergent insects flying to the surrounding watershed. Auerbach ${ }^{3}$ questioned their conclusions because the quantities of radioactivity transported by insects were less than that accumulated from fall-out. However, it was noted that lack of data on emergent insects biomass made it difficult to test the general applicebility of the hypothesis. The purpose of this communication is to assess the role of cmergent Chironomidae as vectors of strontium-90 and freshwater clams as reservoirs of strontium-90 in the Clinch and Tennessee Rivers.

A comprehensive investigation of the fate of low-level radioactive wastes released by Oak Ridge National Laboratory to the Clinch River has been in progress since 1959 (ref. 4). In connexion with this investigation a large collection of adult chironomids was caught in an insect light trap operated on the Clinch River bank at dusk. Theso adult chironomids contained $3.55+1 \cdot 13 \times 10^{-6} \mu \mathrm{c}$ strontium-90/g or 8.76 times as much strontium-90 activity as an equal quantity of river-bottom sediment from that location. Investigations elsewhere ${ }^{5-7}$ have shown emergent chironomid biomass ranges from several up to about $20 \mathrm{~g} / \mathrm{m}^{2} /$ year, the higher productivities arising from eutrophic situations. The Clinch River is not greatly enriched with organic matter, therefore a productivity in the River of $10 \mathrm{~g} / \mathrm{m}^{2} /$ year is a reasonable estimate. With this productivity emergent chironomids would remove $3.55 \pm 1.13 \times 10^{-5} \quad \mu \mathrm{c}$. strontium-90/m² $/$ year from the river bottom. The average increment of stron. tium-90 from fall-out in the United States ${ }^{8}$ between 1959 and 1960 was $4.2 \times 10^{-3} \mathrm{c} . / \mathrm{mile}^{2}\left(1.62 \times 10^{-3} \mu \mathrm{c} . / \mathrm{m}^{2}\right)$. Thus, fall-out entering the River directly would add 45 times as much strontium-90 as was removed by the emerging chironomids. Movement of insects from a contaminated terrestrial environment was found to play a similar inconsequential part in the dispersal of radioactivity ${ }^{8}$. It is apparent that the general dispersion of strontium-90 by insects is not of great importance.

Previous investigations ${ }^{10}$ showed that freshwater clams concentrated strontium in their shells by factors of 2,500-9,000 times that in water and therefore are useful as indicators of strontium 90 in the environment. Since there is a commercial clam fishery on the Tennessee River downstream from the confluence of the Clinch River, calculations were made to estimate the removal of strontium-90 from the River in clam shells. The annual harvest ${ }^{11}$ of shells ranges from about $4.5 \times 10^{9}$ to $9 \times 10^{9} \mathrm{~g}$. By using the maximum harvest and the average strontium-90 concentration in clam shells $\left(7 \cdot 0 \times 10^{-8} \mu \mathrm{c} . / \mathrm{g}\right)$, the calculated removal of strontium-90 was $63 \mathrm{mc} / \mathrm{year}$. If strontium-90 releases were constant, and if growth of the population was in equilibrium with the harvest, a similar amount of strontium-90 would be incorporated into the population each year. These molluse populations were investigated recently ${ }^{12}$ and from this investigation we can estimate a total population of approximately $4.5 \times 10^{7}$ clams in this area. Assuming a weight of $250 \mathrm{~g}$ for each clam (actually a high value) and using the average strontium-90 concentration, the reservoir of strontium-90 in the clams in the river is $79 \mathrm{mc}$. The annual removal and reservoir of strontium-90 in clams is small when compared with laboratory releases of strontium-90, which in the past have ranged from 22 to 150 c./year ${ }^{13}$.
An organism having a significant biogeochemical effect on the distribution of an element in Nature must concentrate an element from its environment. In the instance of strontium-90 in molluses, even though there is a significant concentration of strontium in their shells, there is no large reservoir of strontium-90. This is due primarily to the low specific activity ratio ${ }^{90} \mathrm{Sr}$ atoms/ total Sr atoms) in the river water. In the Tennessee River ${ }^{10}$ there are approximately $10^{10}$ atoms of stable strontium for each atom of strontium-90. This ratio suggests that it would be exceedingly improbable for significant quantities of strontium-90 to occur in biological reservoirs. Parker ${ }^{14}$ estimated the total biomass that might be present in the Clinch River at any one time, and by using the maximum observed strontium-90 and cæsium-137 concentrations in fish, calculated that at most $39 \mathrm{mc}$. of strontium-90 and $8 \mathrm{mc}$. of cæsium-137 would be present in the fish population.

The transport of radionuclides by organisms within a stream $^{15}$ as well as from a stream ${ }^{1}$ has been investigated. Detection of contaminated insects is a useful tool for examining their biology, but, when mass movement of radioactive material is considered, quantities are small. Localized problems may exist ${ }^{1}$, but a general contamination of the landscape by mobile organisms is unlikely.

Radiation Ecology Section, Health Physics Division,

Oak Ridge National Laboratory. Oak Ridge, Tennessee.

${ }^{1}$ Davis, J. J., J. Amer. Water Works Assoc., 50, 1505 (1958)

'Peredelskii, A. A., and Bogatyrev, I. O., Izv. Akad. Nauk S.S.S.R., Seriya Biologiches Kaya, 2, 186 (1959).

${ }^{3}$ Auerbach, S. I., Nuclear Safety, 1, 64 (1959).

${ }^{4}$ Morton, R. J. (edit.) U.S. AEC Doc. ORNL-3119 (1961); ORNL-3202 (1962); ORNT-3370 (1962).

' Odum, H. T., Ecol. Monogr.,27, 55 (1957)

'Teal, J. M., Ecol. Monogr., 27, 283 (1957).

7 Dugdale, R. C. (unpublished thesis), quoted from Lee, G. F., Wisc. Acad. Sci., 51, 141 (1962)

${ }^{8}$ Hardy, jun., E. P., et al., U.S. AEC Doc. TID-17090 (1962).

$\checkmark$ Crossley, jun., D. A., in Radioecology, edit. by Schultz, Vincent, and Klement, jun., A. W., 103 (Reinhold, New York, 1963).

${ }^{10}$ Nelson, D. J., Science, 137, 38 (1962).

${ }_{11}$ Tennessee Valley A uthority, Div. Forestry Dev., Ann. Rep. (1963).

1a Scruggs, jun., G. D., U.S. Dept. Interior, Special Sci. Rep. Fisheries, No. 370 $(1960)$.

${ }^{13}$ Cowser, K. E., in U.S. AEC Doc. TID-7664, 17 (1963).

14 Parker, F. L., in U.S. AEC Doc. TID-7664, 161 (1963).

${ }^{15}$ Ball, R. C., Wojtalik, T. A., and Hooper, F. F., Papers Mich. Acad. Sci., 48, 57 (1963).

\section{Potentiation of Virus Leukæmogenesis in C57BL Mice by $\mathbf{X}$-irradiation or Urethane}

LYMPHOID tumours can be induced in high incidence in strain C57BL mice by fractionated whole-body $\mathrm{X}$-irradiation ${ }^{1}$. Urethane has also been shown to act as an independent leukæmogenic agent when administered to $C 57 B L$ mice shortly after birth ${ }^{2}$. In adult mice, urethane acts as a co-leukæmogenic agent, potentiating the leukæmogenic effects of radiation or other carcinogenic agents, but exhibits little or no leukæmogenic activity when used alone ${ }^{3}$.

The aim of the work recorded here was to examine the effect of X-irradiation and of urethane on lymphoma development induced by a virus (RLV) isolated from radiation-induced leukæmia of strain $C 57 B L$ mice ${ }^{4}$ and serially passaged in this and other strains for more than fifteen generations. It has previously been established that a high incidence of lymphoid tumours can be induced in $C 57 B L$ mice by neonatal inoculation of $R^{2} V^{4,5}$.

Strain $C 57 B L / K a$ mice of various ages were used in all experiments. RLV was obtained from virus-induced lymphoid tumours of strain C57BL mice. The pooled thymus glands, spleens, and lymph nodes were homogenized in 9 volumes of chilled phosphate-buffered saline. 